\title{
INCREASING THE TEMPO OF READING USING A COMPUTER SIMULATION
}

Marek NAGY*, Univerzita Komenského v Bratislave, Slovensko

Přijato: 31. 5. 2018 / Akceptováno: 2. 9.2018

Typ článku: Empirická studie

DOI: $10.5507 /$ jtie.2018.008

Abstract: The article presents an experimental method of training reading aloud in the third grade of primary education. Reading aloud is an important intermediate step towards reading comprehension and reflects the state of perception of words as a whole. Its typical measurable attribute is the reading tempo, the appropriate level of which is necessary, but not sufficient, as a condition for understanding the text. The low tempo is also a demotivating factor and discourages further reading "for joy". For training purpose it was used Multimedia Reader, where children read the text into the microphone and the computer automatically checks and evaluates the recording. During the reading, the simulation of their previous performance is visualized and they try to overcome it.

Key words: primary education, reading aloud, computer simulation.

\section{ZVYŠOVANIE TEMPA HLASNÉHO ČÍTANIA POMOCOU POČÍTAČOVEJ SIMULÁCIE}

Abstrakt: Článok prezentuje experimentálnu metódu nácviku hlasného čitania $v$ tretom ročníku primárneho vzdelávania. Hlasné čitanie je dôležitý medzikrok ku čitaniu s porozumením a odzrkadluje stav vnímania slov ako celkov. Jeho typickým meratelným atribútom je tempo čítania, ktorého vhodná úroveñ je nutnou, nie však postačujúcou, podmienkou porozumenia textu. Nízke tempo je zároveñ aj demotivujúcim faktorom a odrádza od d'alšieho čitania ,pre radost"“. Na nácvik bola využitá aplikácia Multimediálna čitanka, kde deti čítajú text do mikrofónu a počitač automaticky kontroluje a vyhodnocuje nahrávku. Počas čítania sa im vizualizuje simulácia ich predošlého výkonu, ktorý sa snažia prekonat'.

Kl'účové slová: primárne vzdelávanie, hlasné čítanie, počítačová simulácia.

*Autor pro korespondenci: mnagy@ii.fmph.uniba.sk 


\section{1 Úvod}

Čítanie s porozumením je základným ciel’om primárneho vzdelávania. Ako medzikrok k čítaniu s porozumením sa využíva nácvik hlasného čítania. Učitel' má jasnú spätnú väzbu o tom, ako žiak napreduje v osvojovaní si písanej reči. Spočiatku mechanické slabikovanie v prvom ročníku sa postupne zlepšuje a deti čítajú slová ako celok. Začínajú dekódovat' ich význam, čo im umožňuje čítat' rýchlejšie. Tento prechod prebieha v období druhého ročníka a na tempe čítania vidiet' zretel'ný posun. Zo štatistických údajov monitorovania tempa čítania sa ukázalo, že v tret'om ročníku sa nárast priemerného tempa hlasného čítania zastavil (vid' obrázok č. 1). Vo štvrtom ročníku stagnácia pretrvávala. Z tohto sa potom vyvinú aj nedostatky v čítaní s porozumením. Nedá sa očakávat', že ked' diet'a, obrazne povedané, slabikuje rýchlost'ou 60 slabík za minútu, bude mat' motiváciu prečítat' text rozsahu 1200 slabík. Trvalo by mu to 20 minút, kedy už aj zabudne, čo čítalo na začiatku. Tento fenomén prerastá až do rozmeru, že diet'a, ked' zbadá dlhší text, je demotivované a ani nezačne čítat'.

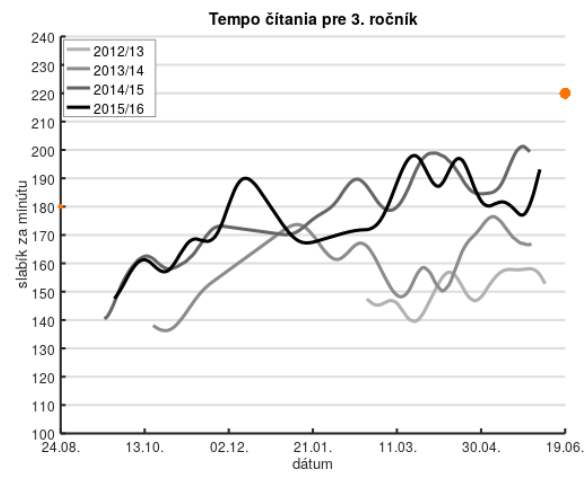

Obr. č. 1: Graf vyhladených kriviek vývoja priemerného tempa čitania tretiakov $v$ štyroch po sebe nasledujúcich školských rokoch. Počet detí je cca 40 v každom roku.

Hlavným ciel'om je nájdenie spôsobu na zlepšenie úrovne hlasného čítania v tret'om ročníku. S triedou sa pracuje ako s celkom, kde možno identifikovat' slabších aj lepších čitatel'ov. Slabších čitatel'ov treba pozitívne motivovat' a dobrých čitatel'ov naopak nedemotivovat', čím sa udrží pozitívna klíma v triede.

\section{Použité metódy}

$\mathrm{Na}$ experiment bola dohodnutá spolupráca so základnou školou, kde sa počet detí v ročníku na primárnom stupni pohybuje okolo 40. Využije sa počítačová webová aplikácia Multimediálna čítanka dostupná na adrese www.mmcitanka.sk. Pomocou nej deti čítajú predložené texty do mikrofónu, počítač ich automaticky skontroluje a zmeria výkony (Nagy, 2017). Deti majú spätnú väzbu v reálnom čase a môžu sledovat', ako napredujú v tempe a plynulosti čítania. Na škole je na tento účel vyčlenená v každom ročníku jedna vyučovacia hodina $v$ počítačovej miestnosti. Typický prvok hodiny je text, ktorý si žiaci najprv vypočujú z originálnej nahrávky a následne ho nahlas prečítajú do mikrofónu. Svoje čítanie opät' počúvajú a „skontrolujú sa“. Zobrazí sa im krivkový 
diagram vývoja tempa a plynulosti ich čítania, kde môžu individuálne sledovat', či sa zlepšili alebo nie. Za zlepšenie sú deti pozitívne hodnotené bodmi. Atribúty čítania textu sa počítajú automaticky pomocou rozpoznávača reči (Nagy, 2017). Podstatou je zmeranie času celkového čítania a jeho dekompozícia na čítaný čas $T_{1}$ a čas ticha $T_{0}$ medzi slovami a vetami:

$$
T=T_{0}+T_{1} \quad[s]
$$

Následne, využitím znalosti počtu slabík textu, možno vypočítat' tempo a plynulost':

$$
\begin{gathered}
\text { tempo }=\frac{\# \text { slabik }}{T_{0}+T_{1}} \cdot 60 \quad[\text { slabik } / \mathrm{min}] \\
\text { plynulost }=\frac{T_{1}}{T_{0}}
\end{gathered}
$$

V tret’om ročníku je pre lepších čitatel’ov v diagrame zavedené zobrazenie hranice, nad ktorou sa stačí „udržat"“, aby boli pridelené body. V tempe bola stanovená hranica na 260 slabík/minútu a v plynulosti hodnota 3 . Toto sú už pomerne vysoké výkony a je problematické z týždňa na týždeň sa prekonávat'. Podl'a štatistických zistení (Hasbrouck \& Tindal, 2006) je priemerné ustálené tempo šiestakov na úrovni 150 slov/minútu. Priemerný počet slabík na slovo je stanovený $\mathrm{z}$ použitých textov $\mathrm{v}$ experimente na dvojnásobok. Zo skúseností hranicu 300 slabík/minútu prekračovali skôr dievčatá ako chlapci. Stávalo sa, že takáto nahrávka sa už stávala nezrozumitel’ná a počítačová kontrola ju zamietala.

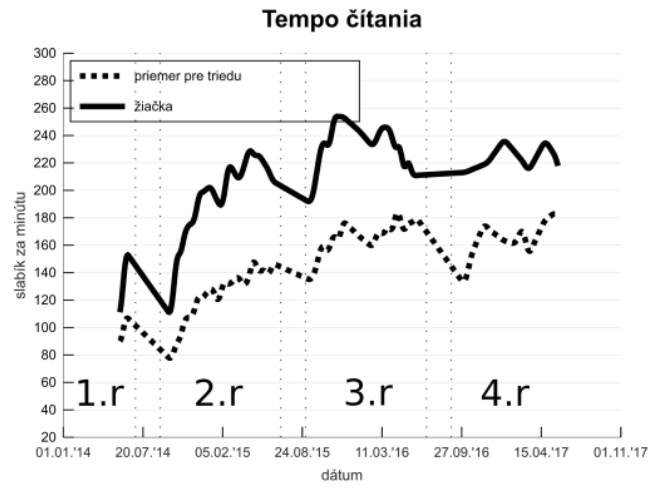

Obr. č. 2: Graf vývoja tempa čitania od 1. po 4. ročnik. Najväčši progres je v 2.ročníku.

Žiaci dostanú spätnú väzbu až po prečítaní celého textu, a tak nemajú prehlad, akým tempom čítat', aby sa zlepšili. Preto bolo zavedené priebežné grafické vyznačovanie pozície $\mathrm{v}$ texte, kde by čitatel' mal byt', aby prekonal svoj výkon z predchádzajúceho týždňa. Takáto spätná väzba je pre deti vel’mi dôležitá. Pri čítaní textu totiž nevedia odhadnút', či je tempo postačujúce na prekonanie sa, alebo treba zrýchlit'. Výsledné tempo 
sa vo forme grafu dozvedia až po prečitaní celého textu, čo už je neskoro. Robilo to problémy a aj dobrí čitatelia boli z výsledku frustrovaní. Kým v druhom ročníku sa deti spontánne z týždňa na týždeň zlepšujú, v tret’om ročníku je to už problematickejšie. Texty sú dlhšie a je potrebné sa sústredit' na obsah. Na obrázku č. 2 je zachytený, na ukážku, vývoj tempa čítania celej triedy (cca 16 detí) a jedného dobrého čitatel’a pred zavedením pomocnej simulácie tempa.

Aby sa deti mohli priebežne kontrolovat' a udržiavat' $\mathrm{v}$ tempe, bolo potrebné realizovat' grafickú vizualizáciu. V iných aplikáciách sú použité vizualizácie formou úpravy fontu a umiestnenia písma (Patel \& Furr, 2011). V práci (Patel \& Furr, 2011) je využité zobrazenie pomocnej zvukovej krivky. Autori (Pervaiz \& Patel, 2014) experimentujú s dynamickým zobrazovaním úrovne hlasitosti. Zobrazovanie a porovnávanie spektrogramu je využité v práci (Vicsi et al., 2000). Rôzne grafické vizualizácie majú však len informatívnu funkciu pri nácviku prozódie. $V$ navrhovanom experimente sa simulovalo tempo čítania pomocou bežiacej značky v texte. Značka je volená menších rozmerov a nevýraznej farby. Je to kvôli tomu, aby zbytočne nerušila, ak diet’a nečíta synchrónne $\mathrm{s}$ ňou. Pohyb značky je prepočítaný na tempo, ktoré diet’a dosiahlo pri predchádzajúcom čítaní pred týždňom. Do rýchlosti pohybu je zakomponovaná aj fyziologická pauza na konci vety. Aby bol posun značky plynulý, pohyb pod slovom je prepočítaný podla počtu slabík, ktorý je získaný z fonetického zápisu.

Celkový čas $\hat{T}$, ktorý by nemal čitatel' prekročit' a tým dodržat' svoje predchádzajúce namerané tempo, možno spočítat' nasledovne:

$$
\hat{T}=\frac{\# \text { slabik }}{\text { tempo } / 60} \quad[s]
$$

Pomocou jednoduchej animácie pohybu bodu pod slovami možno zobrazovat’ aktuálnu pozíciu, kde by sa mal čitatel' nachádzat'. Experimenty tohto typu animácie však boli príliš vyčerpávajúce. Deti nevedeli rozložit nádychy tak, aby dosiahli súbežnost'. $\mathrm{Z}$ tohto dôvodu boli rozpočítané aj pauzy. T.j. celkový čas $\hat{T}$ sa pomerne rozloží na čas ticha $\hat{T}_{0}$ a čas reči $\hat{T}_{1}$. Pomer je určený podla experimentálne zistenej optimálnej plynulosti (Nagy, 2017):

$$
\text { optimalnaPlynulost }=\frac{\hat{T}_{1}}{\hat{T}_{0}}=3
$$

Na základe vzorca (5) je rozklad vypočítaný nasledovne. Pre ticho:

$$
\begin{aligned}
\hat{T} & =\hat{T}_{0}+\hat{T}_{1}=\hat{T}_{0}+3 \cdot \hat{T}_{0} \\
\hat{T}_{0} & =\hat{T} \cdot 0,25
\end{aligned}
$$

a pre čítanie:

$$
\begin{aligned}
\hat{T} & =\hat{T}_{0}+\hat{T}_{1}=\frac{\hat{T}_{1}}{3}+\hat{T}_{1} \\
\hat{T}_{1} & =\hat{T} \cdot 0,75
\end{aligned}
$$

Čas pauzy medzi slovami (za slovami) je vyjadrený nasledovne: 


$$
\hat{t}_{0}=\frac{\hat{T}_{0}}{\# s l o v}
$$

$\mathrm{Na}$ nádych na konci vety je to však príliš krátky čas. Preto bol čas medzi vetami experimentálne predĺžený na desat'násobok pauzy medzi slovami $\left(10 \cdot \hat{t}_{0}\right)$. Nakol'ko je na konci vety aj slovo, je potrebné znížit' počet slov o počet viet a vety zarátat' 10-krát. Vzorec (8) sa zmení nasledovne:

$$
\hat{t}_{0}=\frac{\hat{T}_{0}}{(\# \text { slov }-\# \text { viet })+10 \cdot \# \text { viet }}=\frac{\hat{T}_{0}}{\# \text { slov }+9 \cdot \# \text { viet }}
$$

Na výpočet času trvania jednotlivých slov je dôležitý výpočet trvania jednej slabiky slova:

$$
\hat{t}_{1}=\frac{\hat{T}_{1}}{\# \text { slabik }}
$$

Následne sa podl'a fonetického zápisu vypočíta počet slabík slova a tým aj jeho časové trvanie.

$\mathrm{Z}$ takto spočítaných údajov bolo možné vierohodnejšie simulovat' pozíciu v texte. Det'om sa čítalo pohodlnejšie a dobrí čitatelia nemali problém čítat' súbežne so zobrazovaním. Tempo bolo zvolené podl'a individuálneho údaju z predchádzajúceho čítania. Ak prekračovalo hodnotu 270, bolo umelo dorovnané na hodnotu 270 slabík/minútu, kde je zahrnutý aj istý „manévrovací“ priestor nad stanovenou ciel'ovou hranicou 260.

\section{Výsledky}

Využitie simulovania pozície čítania v texte zaznamenalo úspech. Dobrí čitatelia sa s prehl'adom udržovali nad stanovenou hranicou 260 slabík/min a začali sa sústredit' na prozodické javy a význam viet. Slabší čitatelia sa na vlne pozitívnych motivácií dopracovali k výkonom, ktoré sa blížili k požadovanej hranici. Každý týždeň sa snažili trochu predbehnút' svoj vlastný výkon, čo sa im aj väčšinou podarilo. Priemer tempa čítania pre celý tretí ročník sa na polroka v 2017/18 dostal k úrovni 230 slabík/min, pričom v predchádzajúcich rokoch tretiaci končili školský rok na priemernom tempe 190 slabík/minútu (pozri obrázok č. 3). V druhom polroku 2017/18 sa tempo nezvyšuje, lebo dobrí čitatelia sa už iba udržujú nad hranicou. Zároveň boli predlžované čítané texty až ku hranici 600 slabík (cca 300 slov). Kým v minulosti takýto rozsah prijímali deti s vel'kou nevôl'ou, teraz ho prečítali pomerne hladko.

V tabul'ke č. 1 možno sledovat' podrobnejšie štatistiky pre jednotlivé ročníky. Počet meraní zodpovedá počtu vyučovacích hodín, ktoré sa realizovali. Stávalo sa, že nie všetci žiaci boli prítomní a tak počet detí kolíše. V každom týždni sa spočítalo priemerné tempo a smerodajná odchýlka. Vzniknutá postupnost' priemerov bola vyhladená lineárnym filtrom a zobrazená $v$ grafe. Kl'účové hodnoty prvého a posledného merania by mali určovat' prírastok. Ako však v tabul'ke a v grafe vidiet', nie vždy to má výpovednú hodnotu. Zaujímavejšie je rátat' prírastok od minimálnej hodnoty po maximálnu. Smerodajné odchýlky vykazujú celkom dobrú stabilitu, nakol'ko skupina detí sa nemení. Všetky maximálne priemery tempa sú na hladine významnosti $\alpha=0.02$ menšie ako maximálna 
hodnota v poslednom ročníku. Podla údajov (Hasbrouck \& Tindal, 2006) možno orientačne tvrdit', že na konci tretej triedy by mali žiaci v priemere dosahovat' úroveň 214 slabík/min, čo bolo aj prekročené.

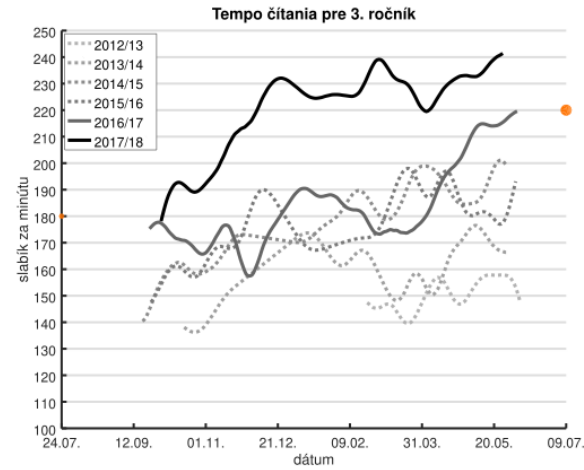

Obr. č. 3: Graf vyhladených kriviek vývoja priemeru tempa čitania tretiakov. Od polovice šk. roku 2016/17 a v šk. roku 2017/18 v spojenís čítaním so simuláciou. Počet detí je cca 40 v každom roku.

\begin{tabular}{|c|c|c|c|c|c|c|c|c|c|c|c|}
\hline \multirow[t]{2}{*}{ Šk. rok } & \multirow[t]{2}{*}{$\begin{array}{l}\text { Počet } \\
\text { meraní }\end{array}$} & \multicolumn{2}{|c|}{$\begin{array}{c}\text { Počet detí } \\
\text { na jedno } \\
\text { meranie }\end{array}$} & \multicolumn{2}{|c|}{$\begin{array}{c}\text { Vývoj } \\
\text { smerodaj. } \\
\text { odchýlok } \\
\text { [slabík/min] }\end{array}$} & \multicolumn{6}{|c|}{$\begin{array}{c}\text { Vývoj priemerov tempa } \\
\text { [slabík/min] }\end{array}$} \\
\hline & & M & SD & M & SD & prv. & pos. & $\Delta$ & $\min$ & $\max$ & $\Delta$ \\
\hline $2012 / 13$ & 14 & 7 & 3 & 29 & 10 & 143 & 119 & -24 & 119 & 164 & 45 \\
\hline 2013/14 & 22 & 21 & 7 & 48 & 7 & 141 & 171 & 30 & 129 & 181 & 52 \\
\hline 2014/15 & 30 & 29 & 8 & 56 & 7 & 160 & 191 & 31 & 127 & 213 & 86 \\
\hline $2015 / 16$ & 30 & 25 & 10 & 49 & 8 & 146 & 200 & 54 & 141 & 216 & 75 \\
\hline 2016/17 & 33 & 26 & 6 & 52 & 8 & 171 & 217 & 46 & 136 & 223 & 87 \\
\hline $2017 / 18$ & 34 & 32 & 11 & 52 & 7 & 144 & 251 & 107 & 144 & 251 & 107 \\
\hline
\end{tabular}

Tab. č. 1: Štatistiky vývoja údajov priemerov a smerodajných odchýlok v priebehu školských rokov, ktoré sú počitané na týždennej báze. Spočitaný je ich celoročný priemer (M) a štandardná odchýlka (SD). V prípade vývoja priemerov tempa je spočitaný rozdiel

(4) medzi posledným (pos.) a prvým (prv.) meraním a tiež medzi maximálnou (max) a minimálnou (min) hodnotou.

Samozrejme, hlasné čítanie nie je ciel’om. Na konci snaženia je čítanie s porozumením. Na tento účel je do experimentálnej vyučovacej hodiny zaradené i zodpovedanie otázok 
$\mathrm{k}$ textu. $\mathrm{V}$ tret'om ročníku pracujú deti s otázkami samostatne. Celkovo možno hodnotit', že úspešnost' odpovedí neklesala, čo je dobrým znakom toho, že zrýchl'ovanie čítania nešlo na úkor porozumenia textu.

\section{Záver}

Nácvik čítania pomocou počítačov aj sám o sebe je pre deti motivujúci. Deti sa $\mathrm{k}$ počítačom tešili. $\mathrm{V}$ závere hodiny sa stihli zahrat' aj niektorú edukačnú aktivitu z Multimediálnej čítanky. Aktivity sú zamerané na čítanie, písanie a počítanie. Celkovo možno priebeh hodiny hodnotit' pozitívne. Samotná simulácia pomohla detom prekonávat' svoje výkony. Deti sa vždy potešili, nakol'ko hodnotenie bolo nepriamo previazané aj na klasické (známkové) hodnotenie slovenského jazyka. Po stabilizovaní čitatel'ských výkonov, mohlo príst' ku zvyšovaniu náročnosti textov. Predlžovali sa a pridávali sa do nich náučné prvky. I čas hodiny bol využitý ovel'a efektívnejšie ako pri klasickej vyučovacej hodine čítania. Všetky deti prečítali celý text, oproti čítaniu v triede, kde sa striedajú a každý číta iba kúsok. Menším organizačným problémom bolo povinné delenie väčšej triedy (viac ako 16 detí) na dve skupiny. Vyriešilo sa to striedaním s anglickým jazykom, kde sa delí tiež. Pri počítačoch tak bolo maximálne 16 detí. Text prečítali a vypočuli za cca. 10 minút a bolo možné venovat' sa d'alším aktivitám. Na klasickej hodine, kde sa deti striedajú v čítaní, môžz každé diet’a (pri počte 16) čítat' max 3 minúty a už je koniec hodiny. Nehovoriac o det'och, ktoré musia v tichosti počúvat'. Do tohto času treba zarátat aj čas strávený udržovaním disciplíny v triede. Pri počítačoch je to iné. Diet’a individuálne plní úlohy, je zamestnané a nemá čas na vyrušovanie.

\section{Literatúra}

Hasbrouck, J., Tindal, G. A. (2006). Oral Reading Fluency Norms: A Valuable Assessment Tool for Reading Teachers. Journal of the Reading Teacher, 59(7), 636-644. doi:10.1598/RT.59.7.3

Patel, R., Furr, W. (2011). ReadN'Karaoke: Visualizing Prosody in Children's Books for Expressive Oral Reading. Proceedings of the SIGCHI Conference on Human Factors in Computing Systems, CHI'11, 3203-3206, ACM, New York. NY. doi:10.1145/1978942.1979417

Vicsi, K., Roach, P., Öster, A. et al. (2000). A Multimedia, Multilingual Teaching and Training System for Children with Speech Disorders. International Journal of Speech Technology 3: 289. doi:10.1023/A:1026563015923

Pervaiz, M., Patel, R. (2014). SpeechOmeter: heads-up monitoring to improve speech clarity. In Proceedings of the 16th international ACM SIGACCESS conference on Computers \& accessibility (ASSETS '14). ACM, New York, NY, USA, 319-320. doi:10.1145/2661334.2661339

Nagy, M. (2017). Measuring and Improving Children's Reading Aloud Attributes by Computers. Journal of Linguistics, 68(2), 278-286. doi:10.1515/jazcas-2017-0037 